\title{
KAJIAN KESESUAIAN DAN EFEK SAMPING PENGGUNAAN KONTRASEPSI PADA AKSEPTOR KONTRASEPSI: STUDI KASUS DI KLINIK HARMONI KOTA SAMARINDA
}

\author{
Siti Ulfah Hidayah ${ }^{1}$, Arsyik Ibrahim ${ }^{1}$, Hajrah$^{1}$, Laode Rijai ${ }^{1}$ \\ ${ }^{1}$ Laboratorium Penelitian dan Pengembangan FARMAKA TROPIS \\ Fakultas Farmasi Universitas Mulawarman Samarinda, Kalimantan Timur \\ Email: sitiulfahhidayah@gmail.com
}

\begin{abstract}
Indonesia as one of developing country formed Keluarga Berencana (KB) program to overcome the population growth rate problem. This program was run by using contraception as a tool or an effort to prevent conception. KB program effectiveness is showed by its duration of use, which is seen by its alternating behavior (contraception acceptability). One of the factors affecting contraception acceptability is its side effect. This study was done to determine the contraception acceptability and its side effect at Harmoni Clinic in Samarinda using cross-sectional method with 84 respondents in total. The result shows that as much as $93 \%$ KB acceptors have change their contraception method and 90 $\%$ of them declaring their reason to change contraception method is its disturbing side effect. Another reasons include difficulties of use (8\%), failed method (1\%) and price (1 $\%)$. Side effects such as increasing body weight was mostly felt by acceptors of pill contraception (47\%), amenorrhea was mostly felt by acceptors of once for three months injection contraception (53 \%), acne breakout was mostly felt by acceptors of pill contraception (43\%), headache is mostly felt by acceptors of pill contraception (40\%), nausea and vomitting was mostly felt by acceptors of once a month injection contraception (35\%), and vaginal bleeding was mostly felt by acceptors of implant contraception (67\%).
\end{abstract}

Key Words: Contraception, Acceptability, Side Effects

\begin{abstract}
ABSTRAK
Indonesia sebagai salah satu negara berkembang membentuk program Keluarga Berencana (KB) untuk mengatasi masalah laju pertumbuhan penduduk. Program ini dilaksanakan dengan menggunakan kontrasepsi sebagai alat atau upaya untuk mencegah kehamilan. Keberhasilan program KB ditunjukkan dari durasi penggunaan kontrasepsi, yaitu dengan melihat perilaku penggantian alat kontrasepsi (kesesuaian penggunaan kontrasepsi). Salah satu faktor yang mempengaruhi kesesuaian kontrasepsi yaitu efek samping. Penelitian ini dilakukan untuk melihat kesesuaian dan efek samping penggunaan kontrasepsi di klinik Harmoni kota Samarinda dengan metode cross sectional dengan jumlah responden sebanyak 84. Hasil penelitian menunjukkan bahwa sebanyak 93\% akseptor KB pernah berpindah metode kontrasepsi dan sebanyak $90 \%$ menyatakan alasan perpindahan tersebut akibat efek samping yang mengganggu. Alasan lainnya termasuk penggunaan yang sulit (8\%), metode gagal (1\%), dan harga (1\%). Efek samping seperti kenaikkan berat badan paling banyak dirasakan oleh akseptor kontrasepsi pil (47 \%), amenorrhea paling banyak dirasakan oleh akseptor kontrasepsi suntik 3 bulan (53\%), jerawat paling banyak dirasakan oleh akseptor pil (43\%), sakit kepala paling banyak dirasakan oleh akseptor pil (40\%),
\end{abstract}


mual-muntah paling banyak dirasakan oleh akseptor suntik 1 bulan (35\%), dan perdarahan paling banyak dirasakan oleh akseptor implan (67\%).

Kata Kunci: Kontrasepsi, Kesesuaian, Efek Samping

\section{PENDAHULUAN}

Jumlah penduduk di provinsi Kalimantan pada tahun 2000 yaitu 2.455.120 jiwa dan meningkat menjadi 3.553.143 jiwa pada tahun 2010. Jumlah tersebut meningkat sebanyak 44,72\% selama 10 dekade terakhir. Laju pertumbuhan penduduk per tahun periode tahun 2010-2014 adalah 2,64\% dan diperkirakan akan terus meningkat (BPS, 2015).

Indonesia sebagai salah satu negara berkembang membentuk program Keluarga Berencana $(\mathrm{KB})$ untuk mengatasi masalah laju pertumbuhan. Program ini menggunakan metode kontrasepsi untuk mengatur dan menjarangkan jarak kehamilan. Istilah kontrasepsi berasal dari kata kontra dan konsepsi. Kontra berarti "melawan" atau "mencegah", sedangkan konsepsi adalah pertemuan antara sel telur yang matang dengan sperma yang mengakibatkan kehamilan. Kontrasepsi berarti menghindari atau mencegah terjadinya kehamilan sebagai akibat adanya pertemuan antara sel telur dengan sel sperma (Suratun, 2008). Kontrasepsi adalah upaya untuk mencegah terjadinya kehamilan, upaya itu dapat bersifat sementara dan dapat pula bersifat permanen (Prawirohardjo, 2008).

Angka kesertaan ber-KB (Contraceptive Prevalence Rate, CPR) di Indonesia pada tahun 2008 diperkirakan sudah mencapai 62\%. Namun besarnya jumlah wanita usia subur (perempuan yang masih dalam usia reproduktif, yaitu antara usia 15-49 tahun) di Indonesia tidak diikuti dengan peningkatan angka kesertaan ber-KB atau CPR. Peningkatan CPR di Indonesia sangat kecil yaitu hanya $0,5 \%$ dalam 5 tahun terakhir, baik pada semua cara KB tradisional maupun pada cara modern (Kemenkes RI, 2013).

Metode kontrasepsi dapat dibedakan menjadi kontrasepsi cara modern dan cara tradisional. Cara modern misalnya sterilisasi, pil, IUD, suntik, susuk $\mathrm{KB}$, kondom, intravagina/diafragma, kontrasepsi darurat dan Metode Amenorea Laktasi (MAL). Cara tradisional misalnya pantang berkala dan senggama terputus (Kemenkes RI, 2013).

Selain diukur dari angka kesertaan ber-KB, keberhasilan program KB juga dipengaruhi oleh efektivitas dan durasi penggunaan kontrasepsi. Oleh karena itu, penting untuk menjaga kelangsungan kontrasepsi dengan melihat perilaku penggantian alat kontrasepsi (kesesuaian penggunaan kontrasepsi) (Rahardja, 2011). Salah satu hal yang mempengaruhi kesesuaian kontrasepsi yaitu efek samping yang ditimbulkan oleh alat kontrasepsi hormonal seperti pil, suntik dan implan dan AKDR dapat menimbulkan efek samping (Prawirohardjo, 2008).

\section{METODE PENELITIAN}

Penelitian ini merupakan studi observasional deskriptif dengan jumlah sampel yaitu 84 responden $(n=84)$ yang diambil dari Klinik Harmoni kota Samarinda pada bulan Okteber 2016.

\section{Alat dan Bahan}

Alat yang digunakan pada peneliatian ini adalah lembar pengumpulan data yang kemudian dianalisis secara deskriptif.

\section{Prosedur Kerja}

Disebarkan lembar pengumpulan data kepada akseptor kontrasepsi, lalu data dianalisa secara deskriptif. Hasil dari analisa digunakan untuk membuat kesimpulan mengenai 
karakteristik wanita usia subur akseptor kontrasepsi, sebaran penggunaan kontrasepsi, kesesuaian penggunaan kontrasepsi, dan efek samping yang ditimbulkan pada akseptor kontrasepsi.

\section{HASIL DAN PEMBAHASAN}

\section{Karakteristik Akseptor Kontrasepsi}

Usia

Berdasarkan pada data yang tertera di Gambar 1, usia akseptor kontrasepsi terbanyak berada pada kelompok 34-41 tahun yaitu sebanyak 68\%.

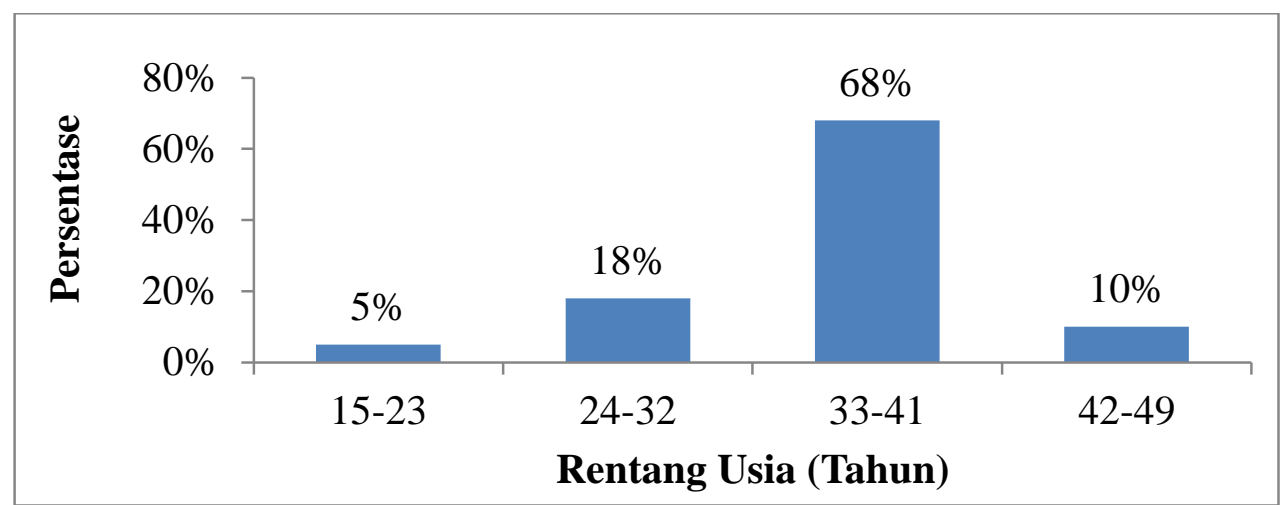

Gambar 1. Karakteristik Usia

Usia mempengaruhi seseorang karena semakin bertambah usia maka seseorang lebih banyak mendapatkan informasi dan pengalaman sehingga secara tidak langsung dapat meingkatkan pemahaman tentang pentingnya kontrasepsi dalam menekan laju pertumbuhan (Notoatmojo, 2010). Pengelompokkan usia dilakukan dengan menggunakan distribusi frekuensi dari semua responden $(n=84)$

Pada kelompok usia 34-41 tahun terdapat sebanyak 68\% pengguna kontrasepsi karena pada wanita usia tersebut diperkirakan telah masuk dalam fase menjarangkan atau menghentikan kehamilan, sedangkan pada kelompok usia 15-23, angka akseptor KB adalah yang paling rendah karena pada usia kelompok tersebut sedang dalam masa reproduksi yang aktif.

\section{Pendidikan Terakhir}

Menurut WHO (2006), tingkat pendidikan mempengaruhi pemilihan metode kontrasepsi. Hal tersebut disebabkan karena tingkat pendidikan yang lebih tinggi mampu menyerap informasi dengan mudah dan memahami pentingnya penggunaan kontrasepsi untuk menekan laju pertumbuhan penduduk (Wahyuningsih, 2015). 


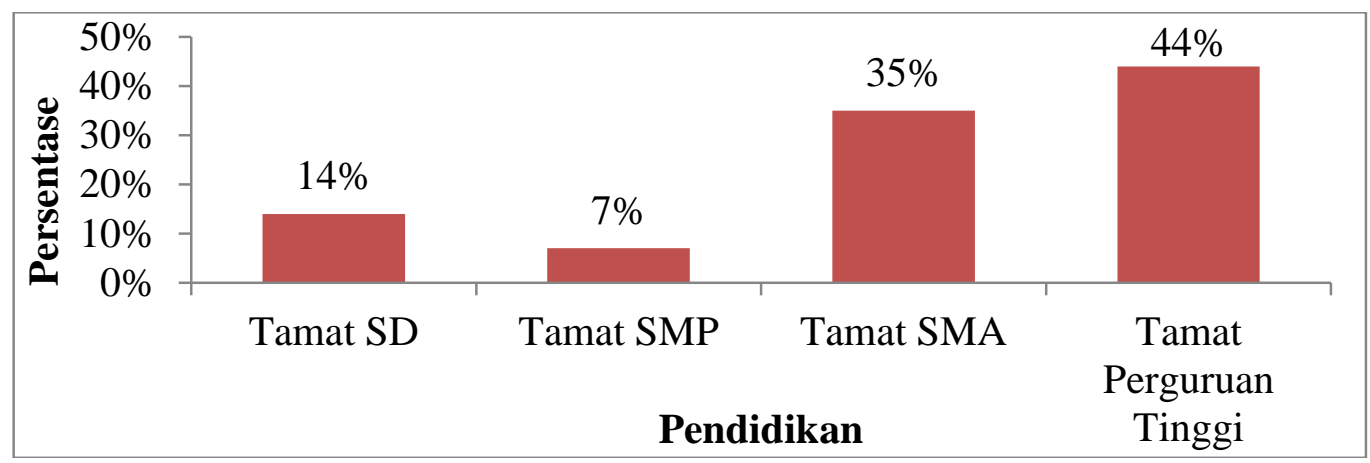

Gambar 2. Karakteristik Pendidikan Terakhir

Hasil penelitian yang ditunjukkan pada Gambar 2 tentang karakteristik pendidikan akhir untuk akseptor kontrasepsi, paling banyak pada kelompok yang tamat pendidikan perguruan tinggi atau akademi yaitu sebanyak 44\%, namun akseptor KB pada kelompok pendidikan akhir SMP adalah yang paling rendah (7\%) bahkan dibandingkan dengan akseptor KB pada kelompok pendidikan akhir SD. Hal tersebut diduga disebabkan karena keputusan untuk menggunakan KB tidak dipengaruhi oleh tingkat pengetahuan seseorang.

\section{Pekerjaan}

Status pekerjaan menggambarkan perkiraan penggunaan waktu sehari-hari oleh akseptor kontrasepsi. Akseptor yang memiliki jam kerja panjang memiliki kecenderuingan untuk memilih kontrasepsi yang frekuensi penggunaannya lebih lama sperti suntik 3 bulan, implan atau AKDR (Alat Kontrasepsi dalam Rahim) (Irianingsih, 2011). Karakteristik ini meliputi pekerjaan IRT (Ibu Rumah Tangga), PNS (Pegawai Negeri Sipil), Pedagang, Buruh dan Swasta.

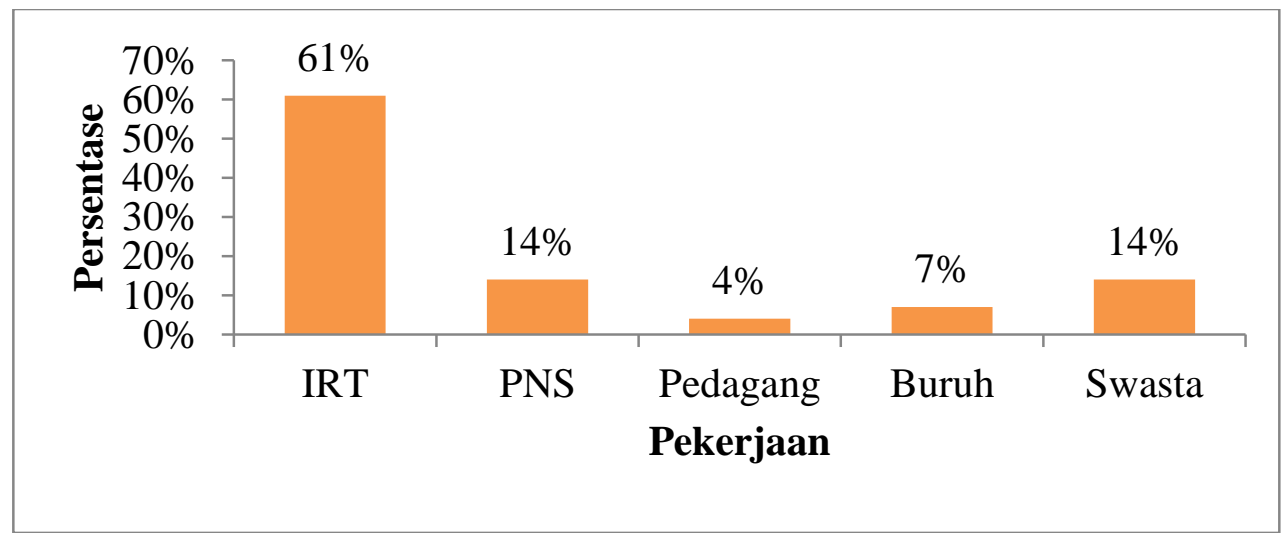

Gambar 3. Karakteristik Pekerjaan

Berdasarkan hasil penelitian yang tertera pada Gambar 3, distribusi pekerjaan akseptor kontrasepsi yaitu terbanyak berada di kelompok ibu rumah tangga/IRT (sebanyak $61 \%)$.

\section{Distribusi Penggunaan Kontrasepsi}

Distribusi penggunaan kontrasepsi yaitu paling banyak menggunakan jenis kontrasepsi pil (40\%), diikuti pengguna suntik 1 bulan (26\%), suntik 3 bulan (23\%), AKDR (6\%) dan implan (5\%). Kontrasepsi pil, suntik 1 bulan, suntik 3 bulan dan implan 
menggunakan kombinasi hormon estrogen dan progesteron atau progesteron saja (Prawirohardjo, 2008). Mekanisme kerja kombinasi estrogen dan progestin (progesteron sintetik) adalah dengan inhibisi selektif terhadap fungsi pituitari yang mengakibatkan pencegahan ovulasi. Kombinasi keduanya juga menghasilkan perubahan mukus serviks, endometrium uterin dan motilitas serta sekresi tuba uterin, dan semuanya mengakibatkan pengurangan kemungkinan konsepsi dan implantasi (Katzung, 2011). Mekanisme AKDR sebagai metode kontrasepsi belum diketahui dengan pasti. Pendapat yang terbanyak adalah bahwa AKDR dalam cavum uteri menimbulkan reaksi peradangan endometrium yang disertai dengan sebukan leukosit yang dapat menghancurkan blastokista atau sperma (Prawirohardjo, 2008).

Hasil menunjukkan bahwa metode pil adalah yang paling banyak dipilih oleh akseptor kontrasepsi (40\%). Keuntungan yang paling utama dari metode kontrasepsi pil adalah dapat diandalkan jika pemakaiannya teratur dan penggunaannya mudah (tidak diperlukan bantuan ahli) (Everett, 2007).

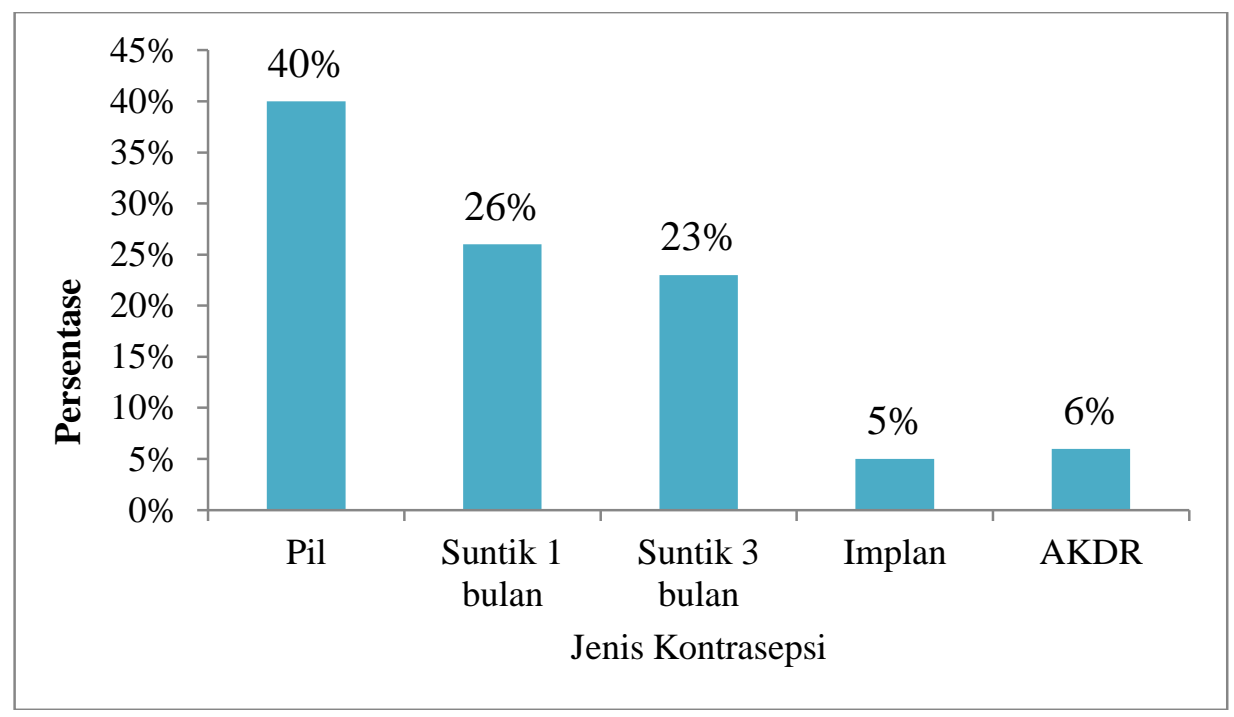

Gambar 4. Distribusi Penggunaan Kontrasepsi

\section{Kesesuaian Penggunaan Kontrasepsi}

Selain diukur dari angka kesertaan ber-KB, keberhasilan program KB juga dipengaruhi oleh efektivitas dan durasi penggunaan kontrasepsi. Oleh karena itu, penting untuk menjaga kelangsungan kontrasepsi dengan melihat perilaku penggantian alat kontrasepsi (kesesuaian penggunaan kontrasepsi) (Rahardja, 2011). Menurut Prawirohardjo (2008), faktor yang mempengaruhi kesesuaian suatu cara kontrasepsi ditentukan oleh beberapa faktor, antara lain: dapat dipercaya, tidak ada atau sedikit efek samping, mudah penggunaannya, dan harga terjangkau. Hasil penelitian menunjukan bahwa 93\% akseptor kontrasepsi pernah berpindah metode kontrasepsi dan 7\% lainnya tidak pernah berpindah metode kontrasepsi. 


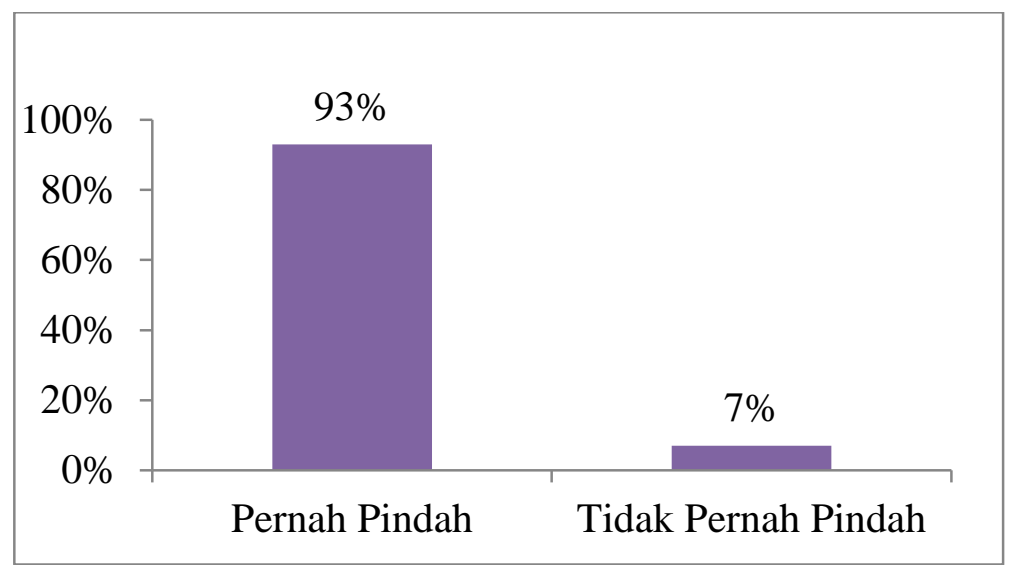

Gambar 5. Pola Pergantian Metode Kontrasepsi

Gambar 6 menunjukkan bahwa alasan berpindahnya metode kontrasepsi oleh akseptor yaitu 90\% karena efek sampingnya yang mengganggu. Alasan lainnya meliputi penggunaan sulit $(8 \%)$ yaitu pada metode kontrasepsi pil frekuensi penggunaannya adalah setiap hari sehingga dapat menyebabkan metode gagal ketika lupa, sedangkan penggunaan sulit yang dimaksud pada metode kontrasepsi suntik, implan dan AKDR adalah penggunaanya harus dibantu oleh tenaga ahli. Selain itu alasan harga dan metode gagal (hamil pada masa mengikuti program KB) masing-masing dirasakan oleh sebanyak 1\% akseptor KB.

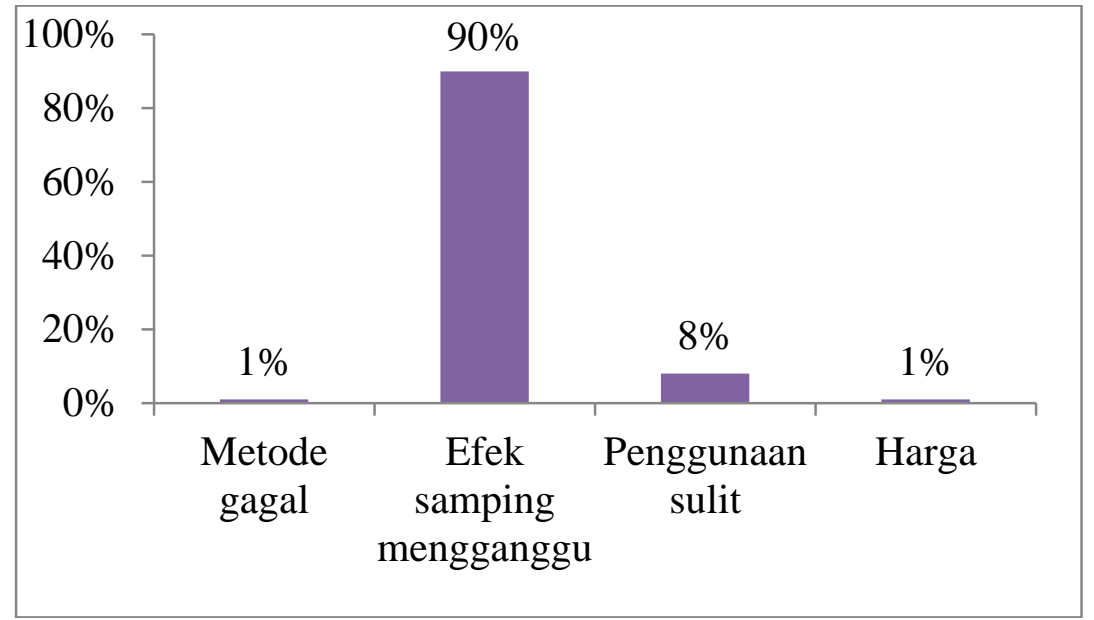

Gambar 6. Alasan Perpindahan Metode Kontrasepsi

\section{Efek Samping Penggunaan Kontrasepsi}

Efek samping merupakan efek tidak diinginkan yang terjadi pada dosis normal yang berhubungan dengan sifat farmakologis (Nebeker, 2006). Hasil penelitian yang ditunjukkan pada tabel 1. menyatakan bahwa efek samping berupa kenaikan berat badan paling banyak dirasakan oleh akseptor kontrasepsi pil. Progestin sebagai derivat dari progesteron diduga sebagai penyebab dari peningkatan berat badan ini (Bony, 2006). Peningkatan berat badan karena adanya peningkatan ukuran pinggul, paha dan payudara disebabkan oleh estrogen, sedangkan progesteron menyebabkan peningkatan nafsu makan (Ballargeon, 2006). Pil kombinasi estrogen dan progestin akan memiliki efek samping peningkatan berat badan yang lebih besar dibandingkan dengan metode lainnya. 
Selain itu, akseptor kontrasepsi pil juga paling banyak mengeluhkan efek samping berupa jerawat (43\%) dan sakit kepala (40\%) dibandingkan dengan metode kontrasepsi lainnya. Menurut Hamani (2007), kontrasepsi pil dengan dosis progestin rendah saja yang dapat menyebabkan jerawat, karena progestin dosis rendah tidak dapat menstimulasi respon hormon androgen. Efek samping berupa sakit kepala dari metode kontrasepsi pil dipengaruhi oleh adanya fluktuasi dari kadar hormon, khususnya pada fase bebas hormon dari penggunaan kontrasepsi oral kombinasi (MacGregor, 2016).

Efek samping berupa amenorrhea paling banyak dirasakan oleh akseptor kontrasepsi metode suntik 3 bulan (53\%). Klinik Harmoni menggunakan nama dagang Depo Provera ${ }^{\circledR}$ yang mengandung Depot Medroksi Progesteron Asetat (DMPA) (Suherman 2007). Dibandingkan dengan metode kontasepsi lain yang hanya menggunakan hormon progesteron, DMPA mengandung kadar progestin yang lebih tinggi (Trussel, 2007). Dosis DMPA selama 90 hari adalah $150 \mathrm{mg}$, secara signifikan lebih tinggi daripada dosis Progestine Only Pills (POP) (31,50 mg) dan implan etonogestrel $(6,3 \mathrm{mg})$ selama 90 hari (Spevack, 2013). Tingginya kadar progesteron pada DMPA diduga menjadi penyebab efek samping amenorrhea. Hasil penelitian ini didukung oleh hasil penelitian Ojule (2010) yang menyatakan bahwa $70 \%$ pengguna DMPA mengalami amenorrhea setelah 2 tahun penggunaan.

Efek samping berupa mual muntah paling banyak dirasakan oleh akseptor kontrasepsi metode suntik 1 bulan (35\%). Kontrasepsi metode suntik 1 bulan yang digunakan di klinik Harmoni adalah Cyclofem ${ }^{\circledR}$ yang mengandung Medroksi Progesteron Asetat $25 \mathrm{mg}$ dan Estrogen Sipionat $5 \mathrm{mg}$ (Suherman, 2007).

Efek samping berupa perdarahan paling banyak dirasakan oleh akseptor kontrasepsi metode implan (67\%). Implan yang digunakan di klinik Harmoni yaitu Norplant ${ }^{\circledR}$ yang terdiri dari 6 tube silastik yang berisi $36 \mathrm{mg}$ levonorgstrel dan digunakan selama lima tahun. Perdarahan merupakan alasan utama seorang akseptor kontrasepsi metode implan untuk mengganti dengan metode yang lain dan hampir sepertiga jumlah pengguna kontrasepsi implan mengalami perdarahan yang berkepanjangan (Rowland, 2014). Pada siklus menstruasi normal, progesteron bertanggung jawab atas dilatasi dan penipisan arteri spiralis (arteri kecil yang menyuplai darah kedalam uterus saat fase luteal di siklus menstruasi). Penggunaan progesteron dosis rendah secara terus menerus mempengaruhi perdarahan karena pembuluh mengalami proliferasi dan menjadi terganggu akibat karena adanya perembesan dari membran dasar dan berkurangnya integritas epitel (Jane, 2014).

Tabel 1. Efek samping penggunaan kontrasepsi

\begin{tabular}{cccccc}
\hline & Pil & Suntik 1 bulan & Suntik 3 bulan & Implan & AKDR \\
\hline BB naik & $47 \%$ & $34 \%$ & $17 \%$ & $2 \%$ & $0 \%$ \\
Amenorrhea & $3 \%$ & $41 \%$ & $53 \%$ & $3 \%$ & $0 \%$ \\
Jerawat & $43 \%$ & $35 \%$ & $13 \%$ & $9 \%$ & $0 \%$ \\
Sakit kepala & $40 \%$ & $30 \%$ & $20 \%$ & $10 \%$ & $0 \%$ \\
Mual/muntah & $23 \%$ & $46 \%$ & $7 \%$ & $24 \%$ & $0 \%$ \\
Perdarahan & $0 \%$ & $0 \%$ & $33 \%$ & $67 \%$ & $0 \%$ \\
& & & & & \\
\hline
\end{tabular}

\section{KESIMPULAN}

Berdasarkan hasil penelitian diketahui bahwa karakteristik usia akseptor kontrasepsi paling banyak adalah kelompok 15-23 tahun (5\%), karakteristik pendidikan terakhir yang paling banyak yaitu kelompok yang menempuh pendidikan perguruan tinggi atau akademi 
(44\%), dan karakteristik pekerjaan yang terbanyak adalah kelompok ibu rumah tangga (tidak bekerja) (61\%). Distribusi penggunaan kontrasepsi yaitu paling banyak digunakan kontrasepsi metode pil (40\%). Sebanyak 93\% akseptor KB pernah berpindah metode kontrasepsi dengan alasan efek samping yang mengganggu (90\%).

\section{DAFTAR PUSTAKA}

Bony A. E., et al., 2006. Weight Gain in Obese and Nonobese Adolescent Girls Inisiating Depot Medroxyprogesteron, Oral Contraceptive Pills, Or Non Hormonal Contraceptive Methods. Arch Pediatr Adolec Med. Vol. 32: 147-153

BPS., 2015. Penduduk Indonesia Menurut Provinsi 1971, 1980, 1990, 1995, 2000 dan 2010. Badan Pusat Statistik

Ballargeon, J., et al. 2006. Association Between The Current Use of Low Dose Oral Contraceptive and Cardiovascular Arterial Disease: A Meta Analysis. J Clin Endocrinal Metab. Vol 90: 3863-3870

Everett, Suzanne., 2007. Buku Saku Kontrasepsi dan Kesehatan Seksual Reproduktif Edisi 2. Jakarta: Buku Kedokteran EGC

Katzung, B. G., et al., 2011. Basic and Clinical Pharmacology $12^{\text {th }}$ Edition. USA: McGraw-Hill Companies

Kemenkes RI., 2013. Situasi Keluarga Berencana di Indonesia. Buletin Jendela Data dan Informasi Kesehatan. ISSN 2088-270X: Vol. 2

Hamani Y., et al., 2007. Misconception About Oral Contraception Pills Among Adolescent and Physicians. Human Reproduction. Vol 22 No. 12: 3078-3083

Irianingsih, H., 2011. Hubungan Lama Pemakaian KB Suntik 3 bulan Depo Progestin dengan Peningkatan Berat Badan pada Akseptor KB di Puskesmas Klego II Kabupaten Boyolali. Surakarta: Fakultas Kedokteran Universitas Muhamadiyah

Jane, D., et al. 2014. Unanticipated Bleeding with Etonogestrel Implant: Advice and Therapeutic Intervention. Journal of Family Planning and Reproductive Health Care. Vol. 40. No 3: 158-160

MacGregor, E. A., 2016. Contraception and Headache.The Journal of Head and Face Pain. Vol 13: 247-276

Notoatmodjo, Soekidjo. 2010. Metodologi Penelitian Kesehatan. Jakarta: Rineka Cipta

Prawirohardjo, S., dkk., 2008. Ilmu Kandunagan. Jakarta: PT Bina Pustaka Sarwono Prawirohardjo

Rahardja, M. B., 2011. Kualitas Pelayanan Keluarga Berencana dan Penggantian Kontrasepsi di Indonesia. Jurnal Kesehatan Masyarakat Nasional. Vol. 6 No.3: 140144

Rowlands, Sam and Stephen Searle. 2014. Contraceptive Implants: Current Perspective. Journal of Contraception. Vol. 5:73-84

Suratun., dkk. 2008. Pelayanan Keluarga Berencana dan Pelayanan Kontrasepsi. Jakarta: Trans Info Media

Spevack, Edra. The Long Term Health Implication of Depo Provera. Integrative Medicine. Vo. 12 No. 1: 27-34 
Suherman, S. K., 2007. Farmakologi dan Terapi Edisi 5. Jakarta: Departemen Farmakologi dan Terapeutik Fakultas Kedokteran UI

Trussel J., et al., 2007. Contraceptive Technology: Nineteenth Revised edition. New York: Ardent Media

Wahyuningsih, N., dkk. 2015. Karakteristik Akseptor Kontrasepsi Suntik DMPA di Desa Gringgin, Sambungmacan, Suragen. Gaster Vol 12. No. 1: 28-35

WHO. 2006. Ragam Metode Kontrasepsi. Jakarta: Buku Kedokteran EGC 